\title{
Those wonderful school days in Sestri Levante!
}

\author{
Marcus Pembrey \\ European Journal of Human Genetics (2017) 25, S13-S15; doi:10.1038/ejhg.2017.143
}

I have such happy memories of the first ten years of the 'European School of Medical Genetics', as the original spring course in Sestri Levante was called. It rapidly became one of the highlights of the academic year for many of those fortunate enough to be invited onto the faculty - and was just referred to as 'Sestri'. I have wondered why Giovanni Romeo approached me with his plan in 1987, especially given my complete inability to learn languages! At the invitation of Amândio Tavares I had been a visiting organiser and examiner of a MSc course in Medical and Human Genetics at the University of Oporto, Portugal between 1985 and 1987. By the time that course got underway Charles Buys (University of Groningen) was the other visiting organiser. Perhaps this-or my use of Lego to explain RFLPs and PCR-was qualification enough for 'Sestri'. What I was not prepared for, when I arrived for the first course, was the stunning location. Not only was Sestri Levante an idyllic town on the Mediterranean sea, 56 kilometres south of Genoa, but the course was to be held in the castle set high up on the promontory between the Bay of Silence and the Bay of Fables! What a place to hold a residential course, modelled, I believe, on McKusick's Bar Harbor course in the US-now in its 58th year. I never went to that course, but colleagues spoke highly of it and its emphasis on student-faculty interaction.

There was certainly plenty of interaction of all kinds at the spring 'Sestri' course. Being held outside the high tourist season, we were all accommodated in a few nearby hotels in the town close to the castle. The climb up the hill first thing did mean the students and faculty arrived fully awake, although whether or not 'invigorated' often depended on the night before! At its most gentle, it would be Jurg Ott playing Scott Joplin Ragtime on the piano; at the other extreme it would be heavy rock on the hotel sound system-but always plenty of dancing. One tradition was the students' light-hearted satirical play/ performance on the last night, which combined entertainment with 'sending-up' faculty members. But the grandest of traditions was the breath-taking walk along the Cinque Terre one afternoon in the middle of the course. Fortunately, not everyone was obliged to reach all five fishing villages. If the ups and downs of the paths along precipitous cliffs linking the villages had taken an early toll on your joints, you could catch the train back to Sestri Levante.
The mix of students and faculty throughout the course meant a relaxed atmosphere that encouraged plenty of questions and exchange. This was particularly so during the several simultaneous afternoon workshops and tutorials (Figure 1). As a faculty member, one had the advantage of learning - not just from the students—but also from the other faculty members. This exchange had a great influence for good in terms of international collaboration in research, training and public engagement. It was an excellent way of keeping up to date. Indeed, a few years on, I remember getting a phone call from an ambitious, rising star in medical genetics asking how one went about getting an invitation to join the faculty! In my own unit at the Institute of Child Health, University College London, those in training or on our MSc course were expected to attend the European School of Medical Genetics.

Giovanni Romeo and Victor McKusick started something of great importance for human and medical genetics with the first European School of Medical Genetics. But importantly, the School has continued to evolve to keep pace with advances in the science and changes in clinical practice within our field. Additional specialised courses were added under the broader umbrella of the European School of Genetic Medicine. I was active- with many others-in the development of the first two courses on Genetic Counselling in 1999 and 2000. But I had finished clinical practice by this time and my research had changed direction. I feel very honoured to have been involved, and when people I barely recognise approach me at meetings, it often turns out that we first met in 'Sestri' many years ago. It brings back happy memories.

Marcus Pembrey

Professor M Pembrey, FRCP, FRCOG, FRCPCH, Office Centre for Child and Adolescent Health, Oakfield House, Oakfield Grove, Clifton BS8 2BN, UK. Tel: +44 (0)11733 14099; E-mail: M.Pembrey@bristol.ac.uk 


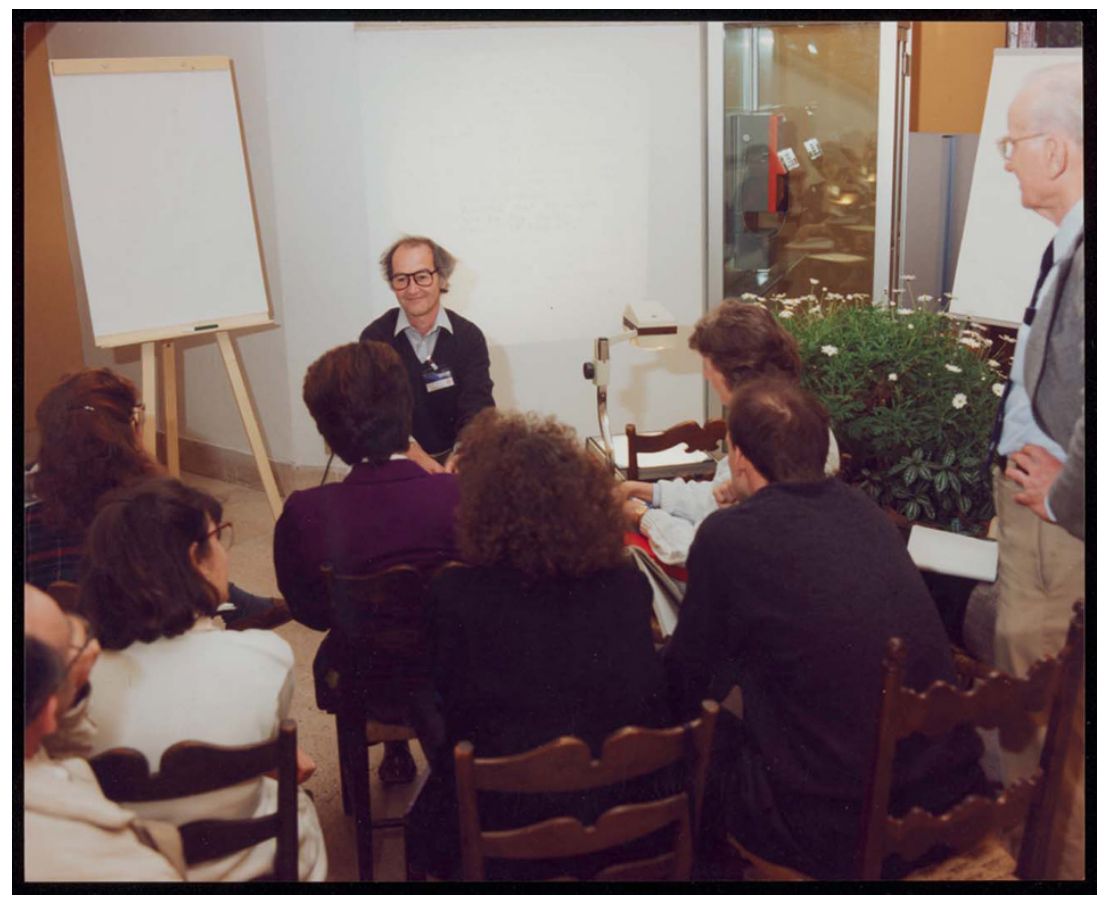

Figure 1 The European School of Medical Genetics. An afternoon tutorial led by Marcus Pembrey with Victor McKusick looking on. Wellcome Library, London. 


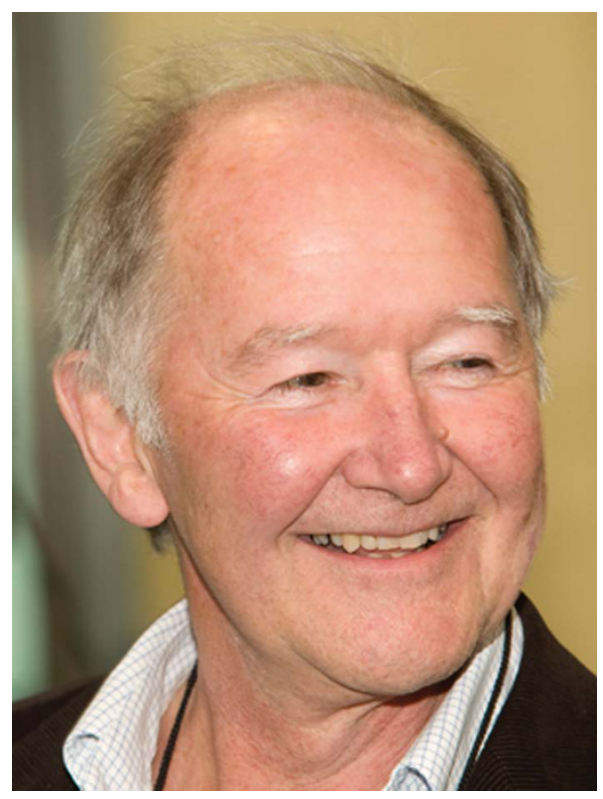

Professor Marcus Pembrey (born 1943) is a clinical geneticist and now Emeritus Professor of Paediatric Genetics at Institute of Child Health, University College London. He is also visiting Professor of Paediatric Genetics at the University of Bristol, where he was Director of Genetics within the Avon Longitudinal Study of Parents and Children from 1989-2005 and still continues his research. He was previously Adviser in Genetics to the Chief Medical Officer at the UK Government's Department of Health for ten years, Vice Dean of the Institute of Child Health and a Consultant Clinical Geneticist at Great Ormond Street Hospital for Children. President of the European Society of Human Genetics in 1994-1995, he was co-founder and ESHG Liaison Officer of the International Federation of Human Genetic Societies 1996-2001. He taught at the European School of Medical Genetics from 1988 for ten years and was co-founder of the Progress Educational Trust UK in 1992, being its Chair for over 20 years. Interested in unusual inheritance patterns, he studied Fragile X and Angelman syndrome during 1980-90 and so onto imprinting and epigenetics more generally. His current research focus is on environmental epigenomics and human inter-/trans-generational responses to early life experiences. He is a Fellow of the UK Academy of Medical Sciences. 